\title{
Impact Of Service Quality On Students Satisfaction In Higher Education Institutions
}

\author{
Roohul Amin \\ Ph.D. scholar, Department of Peace \& Conflict Studies, National Defense \\ University, Islamabad \\ rua58@yahoo.com \\ Dr. Asma Khuwaja \\ Associate Professor, Department of Peace \& Conflict Studies, National Defense \\ University, Islamabad \\ NisarAfridi \\ PhD Research Scholar, Islamia College Peshawar \\ nisar.afridi20@yahoo.com
}

\begin{abstract}
In prevalent competitive environment of higher education institutions it has become vital for the institutional management to pursue for attainment of students satisfaction and maintain it throughout their stay in the institution during the course of study. Besides many predictors, the service quality is considered very vital factor in education sector to ensure students satisfaction all along their learning stage. Therefore, this research study aims to measure the relationship between the service qualities of higher education institutions with their customers (students) satisfaction. The service quality of higher education is determined by measuring various dimensions of service quality such as; the tangibility of institution and its infrastructure, reliability in its service delivery, responsiveness of its service providers, assurance and empathy. The research furthers its measurement of relationship of each dimension of service quality with students satisfaction level with a view to ascertain significance of each or otherwise. The research intends to investigate students of public and private sector universities of Khyber Pakhtunkhwa. The research is not only expected to determine the prevalent level students satisfaction and service quality of higher education, but also help to draw a comparative analyses between the public and private sector in this regard. The research would help the management of higher education institutions to revisit and regulate their strategies to deliver better service quality to its customers by focusing each dimension of the service quality individually.
\end{abstract}

Key words: Customers satisfaction, Service quality, Intangibility, Reliability, responsiveness, assurance, empathy, Higher education institutions, Khyber Pakhtunkhwa.

\section{Introduction}

There is no denying the fact that the education is a making or breaking factor for the human development of any nation and serves as a foundation of sectorial 
development. Education is a primary source for individual development through all forms of learning, provision and enhancement of knowledge, acquisition of skills and nurturing of positive values and habits which are to be carried from one generation to the next. The return on nation's investment in education sector is always multiplied in manifolds and various sectors. Today a cursory look over community of nations reveals that those nations who are ranked at higher position in education are also occupying better position in global economic, development, innovation and human right ranking as well. Education equips peoplewith the knowledge and skills that help them to pull them and their society out of poverty and into fortune; and prepare them to preventand thwart illness. However, the returns from education for society is directly correlated with the soundness, relevancy and quality of education provided for the purpose.

Education of any nations, including Pakistan, revolves around three tiers system i.e. fromprimary or basic education, through secondary (K-12) and higher education at universitylevel. Most of the professional education institutions of today are also clubbed with the higher education sector and add in to its significance further. The socio-economic or socio-political development of any society is mainly an outcome of veracity and versatility of higher education infrastructure in that society. Today's higher education institutions are more dynamic and more versatile in their nature, areas, contents and methods of delivery.Contemporary universities and their campuses provide their learners with numerousprogramsdesignedfor preparing them forlabour / job market, for various economic generating sectors, technology and industry operators, health workers, and enabling them to keep pace with modifications in the innovation process.

Being centralsocket of knowledge creation, knowledge transfer and application higher education institutions are acknowledged as precursor of nation's sustainable socio- economic development across the globe. Therefore, higher education is largely defined as one of predominant drivers of raising skills, improved national and organizational performance, social prosperity, economic growth and competitiveness. Capitalizing in knowledge creation and facilitating transmissionof higher education enables nation to drive innovative solutions in confronting global challenges in the domains of food security, technological advancement, healthcare, business and labour markets, environment and human security, intellectual capital international connectivity development.

Without undermining the need for quantity and diversity of higher education institutions, there cannot be any compromise on the quality of contents of educational programs and their service delivery to the recipients- the students. Pakistan used to be far behind in provision of higher education just two decades before because of lack of its infrastructure. Pakistan witnessed unprecedented growth in higher education in $21^{\text {st }}$ century and invested in its quantity and quality simultaneously. On September 2001 the province of Khyber Pakhtunkhaw (KP) has only four public sector universities (two general universities and one Agricultural \&one Engineering) with GhulamIshaq Khan Institute as a semi private engineering outfit. Whereas, as of today, KP is being served with 32 universities including nine private sector universities excluding private Medical 
colleges. It is beyond any doubt that such an unprecedented growth in higher education institutions have satisfied need of KP population up to larger extent. However, there is need to ensure that quality in provision of higher education is not compromised at any cost and in any institutions.

With this background in view, it is stated that Pakistan's economic profile cannot lavishly support and sponsor universities for a longer run. The universities have to plan and work for their sustained growth with purpose oriented public delivery. And this is possible, only, if their graduates are satisfied with their learning cycle and the country is enriched with their contribution on their entry in the national market. Institutions carry their image through their alumni and act as source of marketing for potential entrants. Failing which the institution will be unable to withstand the pressures of market competitiveness and turn in to declining trajectory to an unsustainable and shutdown position. It is the satisfied students which attracts the potential students' intake toa large scale and yield financial and market resources to manage university's operational and growing need.

Foregoing in view, there is need for the university management to know the prevailing degree of student's satisfaction and the quality of their education service provision operation so as to take stock of the situation. The research exercise for determination of prevalent level of students' satisfaction and quality of education service provision would serve as an audit platform of their performance. The research findings would help the universities management to revisit their institutional strategies with regards to the service quality encompassing all quality dimensions including; tangibility of infrastructure; reliability of operation about service provision; responsiveness of the university management, faculty and staff; assurance; and empathy. If these quality dimensions are found ranking higher side on the scale that is expected to result in to meeting students' expectations and turning them in to satisfied customers.

This research paper seeks investigate relationship between the various dimensions of service quality and the students satisfaction. To determine this impacting relationship, the research planned to approach students of three each from public and private sectors universities with a view to ascertain their perceptions with regard to perceived service quality and students satisfaction level.

\section{Objectives of the Study}

- To determine the degree of association between tangibility of service quality and customer satisfaction

- To determine the degree of association between reliability of the service quality and customer satisfaction

- To determine thedegree ofassociation between responsiveness and customer satisfaction

- To determine the degree of association between assurance and customer satisfaction

- To determine the degree of association between empathy and customer satisfaction 


\section{Salient from Review of Literature}

Higher education is a corner stone for the development of a nation. Universities in Pakistan are expanding very rapidly from the last couple of years. Both types of universities put maximum efforts to provide standard quality of service to its stakeholders. Higher education sector of Pakistan needs special attention from the government as well as from general public, as superior quality of education brings economic and social development of nation. Currently quality considers a strategic instrument for the development and success of higher education institutions to remain ahead from the competitor by delivering high quality of services in the market. Service quality considers a fighting tool for the customer satisfaction and competitiveness of the organization. It is imperative for higher education institutions to have a well-furnished infrastructure, physical facilities, well qualified academic staff, well-furnished computer labs and libraries, courteous employees, accessibility to academic and non-academic staff, availability of staff, reliability of the employees, responsiveness of the employees, assurance and empathy behaviour of the employees.

Parasuraman et al. (1988) define service quality is the difference between perception and expectation. In other words service quality is evaluated by comparison of customer perception with expectation $(\mathrm{SQ}=\mathrm{P}-\mathrm{E})$. SERVQUAL measurement scale have been widely applied in different sectors by different researchers such as travel and tourism (Fick, 1991), architectural services (Baker and Lamb, 1993), banking sector (khan and Fasih, 2014, Quyet, Vinh and Chang, 2015, Lee and Moghavvemi, 2015, Suvittawat, 2015), fast food sector (Tan, Oriade and Fallon, 2014) and IT sector (Alsaleh and Bageel, 2015). SERVQUAL is universally applicable and valid instrument used for comparative benchmarking purposes (Shahin, n.d) and also because of its easiness to use, possession of a simple structure and capability of generalization (Parasuraman et al, 1988). SERVQUAL and its adaptation have been extensively applicable in different industries such as banking, health, education, telephone, credit card and retail (Narang, 2012, Parasuraman et el. 1985, 1988; Cronin \& Taylor, 1992; Daholkar et al. 1996). A research study was conducted in Poland GSM industry by Cumhur and Aydinli in 2016. The title of the study was measuring impact of service quality dimensions on customer satisfaction: case of GSM users in Poland and variable of the study was service quality, service quality dimensions and customer satisfaction. The survey method was used to collect data from respondents with the help of SERVQUAL model dimensions. After analyzing the data the most important dimensions were tangibles, assurance and reliability. The future call of the study was that researcher may increase the number of participants that could more clear the accuracy of the results (CumhurAydinli, 2016).

Customers are the most valuable asset for the organization for which they compete in the market (Pandit, 2016). According to Kotler (1991) customer satisfaction is a comparison of pre-purchase and post-purchase perception. Kotler (1996) defined customer satisfaction as the "the level of persons felt resulting from comparing a product's perceived performance or outcome in violation to his/her own expectations". Hence customer satisfaction is a comparative behavior between 
inputs beforehand and post obtainments. Similarly "Satisfaction is the subjective opinion, it is the benefit that customer get from purchasing products or services" (Ostrom\&Iacobuci, 1995). In the view of Anderson, Fornell and Lehman (1994) customer satisfaction is the overall experience of customers having after the consumption of services. It is a collective perception that will affect service quality and repurchase intention. Customer satisfaction should be the ultimate goal of all organization and it is also essential for the survival of the organization (Muhammad et al. 2018). Elliott and Shin (2002), describe the students satisfaction as the favourability of a student subjective evaluation of the various outcome and experience associated with education. In higher education context, student satisfaction occurs when perceived performance meets or exceeds the students' expectation (Mark, 2013).

Customer satisfaction may be defined as the attainment of the requirements for which a service or goods delivery was completed (Asaleh\&Bageel, 2016). In the view of Rust and Oliver (1994) satisfaction as the "customer fulfilment response", which reveals a customer evaluation and emotion based response toward a service. Although (Mosahab, Mahamad, \&Ramayah, 2010) define that customer satisfaction is the difference between expectation and performance but still differences are exists between quality and satisfaction. For example expectation for goods is "would" in satisfaction literature while expectation for goods is "should" in service quality literature. The relationship between service quality and customers satisfaction is a controversial issue in the review of literature. But number of researchers for instance (Cronin and Taylor, 1992; Oliver, 1997; Ting, 2004; Kim et al. 2009) still supported that service quality is the main driver of customers' satisfaction.

\section{Conceptual Framework}

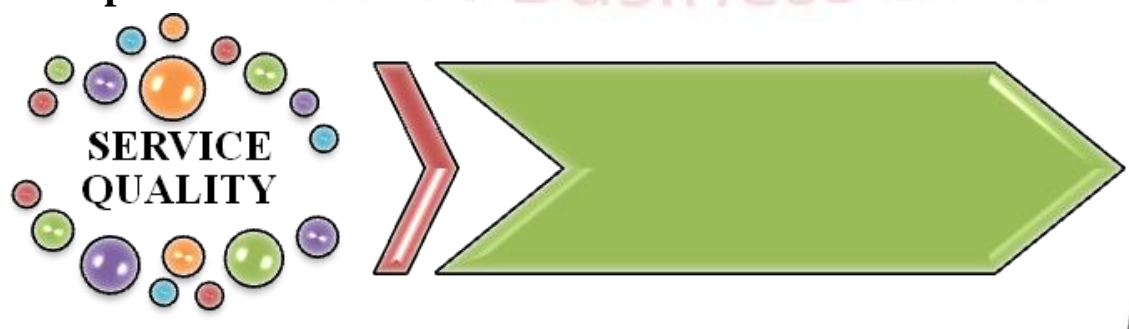

* Tangiblity

*Reliability

* Responisveness

* Assurance

* Empathy

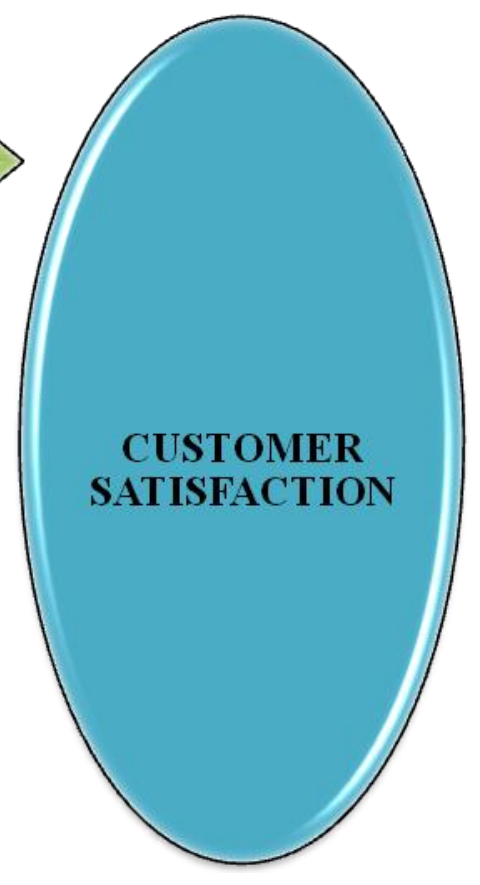


Hypotheses:A set of hypotheses developed from the theoreticalframework is as follow:

H1: There is significant relationship between tangibility of service quality and students satisfaction.

H2: There is significant relationship between reliability of service quality and students satisfaction.

H3: There is significant relationship between responsiveness of service quality and students satisfaction.

H4: There is significant relationship between assurance of service quality and students satisfaction.

H5: There is significant relationship between empathy of service quality and students satisfaction.

\section{RESEARCH METHODOLOGY}

Population may be defined as a set of all the elements about which a researcher intends to make an assumption (Ducombe\&Boateng, 2009). The target population of the study was both sector universities of Khyber Pakhtunkhwa. The sample of the study was selected with the help of Krejice and Morgan formula. The proportionate sample technique was used to select sample from the target population. Stratified sampling technique was used in the second stage to draw sample from the students. The data was randomly collected from 490 students of both sector universities. The structured questionnaire was distributed among the respondents based on five point likert scale i.e. from strongly disagree to strongly agree. Basically there were two parts of the questionnaire, section A contains questions about service quality and section B consists of customer satisfaction. The collected data was finally analysed with the help of SPSS software.

\section{Data Analysis}

Table 1 Demographic Profile of the Respondents

\begin{tabular}{|c|c|c|c|}
\hline \multicolumn{2}{|c|}{ Demographic Variables } & \multicolumn{2}{|c|}{ Research Sample $(n=490)$} \\
\hline & & $\begin{array}{c}\text { No. of } \\
\text { Respondents }\end{array}$ & Percentage \\
\hline $\begin{array}{l}\text { Public \& Private } \\
\text { Universities }\end{array}$ & $\begin{array}{l}\text { Khyber } \\
\text { Pakhtunkhwa }\end{array}$ & 490 & $100 \%$ \\
\hline \multirow{2}{*}{ Gender } & Male & 397 & $81 \%$ \\
\hline & Female & 93 & $19 \%$ \\
\hline \multirow[t]{4}{*}{ Education } & Bachelor & 184 & $37.5 \%$ \\
\hline & Master & 223 & $45.5 \%$ \\
\hline & MS/M.Phil. & 60 & $12.2 \%$ \\
\hline & $\mathrm{PhD}$ & 23 & $4.7 \%$ \\
\hline
\end{tabular}




\begin{tabular}{|l|l|c|c|}
\hline \multirow{4}{*}{ Age } & & & \\
\cline { 2 - 4 } & $17-21$ & 84 & $17.1 \%$ \\
\cline { 2 - 4 } & $21-25$ & 259 & $52.8 \%$ \\
\cline { 2 - 4 } & $26-30$ & 76 & $15.5 \%$ \\
\cline { 2 - 4 } & $30-34$ & 44 & $5.7 \%$ \\
\cline { 2 - 4 } & $34+$ & 27 & $9.0 \%$ \\
\hline
\end{tabular}

Table no.1 abovereflects the demographic profile of the respondents of the public and private universities of Khyber Pakhtunkhwa. There are 490 respondents approached from both public and private sector universities out of which 397 were male and 93 were female with the percentage of $81 \%$ and 19 $\%$ respectively. The majority number $223(45.5 \%)$ students were studying in master classes, $184(37.5 \%)$ in bachelor classes, 60 (12.2\%) and $23(4.7 \%$.) studying in M.Phil. and $\mathrm{PhD}$ classes respectively. The above table further depicts the age of the respondents included in this study, where the majority of the respondents were in the range of 21-25 years.

Table 2 Tests of Normality

\begin{tabular}{|l|r|r|r|r|r|r|}
\hline & \multicolumn{3}{|c|}{ Kolmogorov-Smirnov $^{\text {a }}$} & \multicolumn{3}{c|}{ Shapiro-Wilk $^{*}$} \\
\cline { 2 - 7 } & Statistic & \multicolumn{1}{c|}{$\mathrm{df}$} & \multicolumn{1}{c|}{ Sig. } & \multicolumn{1}{c|}{ Statistic } & \multicolumn{1}{c|}{ df } & \multicolumn{1}{c|}{ Sig. } \\
\hline Tangible & .301 & 253 & .100 & .727 & 253 & .200 \\
Reliability & .298 & 253 & .100 & .782 & 253 & .200 \\
Responsiveness & .229 & 253 & .200 & .865 & 253 & .300 \\
Assurance & .266 & 253 & .100 & .770 & 253 & .200 \\
Empathy & .279 & 253 & .100 & .742 & 253 & .100 \\
\hline
\end{tabular}

Table 2 shows the tests of normality overlay a normal curve on actual data, to assess the fit. A significant test means the fit is poor. For the tangible, reliability, responsiveness, assurance and empathy factors, the test is not significant; they fit the normal curve well. However, if, the test is significant; they fit the normal curve poorly.

Table 3 KMO and Bartlett's Test

\begin{tabular}{|c|c|c|}
\hline & .875 \\
\hline \multicolumn{2}{|c|}{ Bartlett's Test of Sphericity Approx. Chi-Square } & 279.948 \\
\hline & df & 21 \\
\hline & Sig. & .000 \\
\hline
\end{tabular}

Table 3 shows KMO value was higher than the recommended value of 0.6 and BTS was significant at $\mathrm{p}<0.05$ level. 
Table 4 Dimension wise Reliability Statistics

\begin{tabular}{|l|l|}
\hline Variables & Cronbach Alpha \\
\hline tangibility & .846 \\
\hline reliability & .754 .761 \\
\hline responsiveness & .856 \\
\hline assurance & .931 \\
\hline empathy & .741 \\
\hline satisfaction & .754 \\
\hline
\end{tabular}

Table 4 is the findings of item wise reliability of the parameters selected for the variables in questionnaire. The values suggested that the Cronbach alpha of the variable is more than .70 which means that the variables selected are reliable.

Table5 Overall Reliability of Service Quality and Customer Satisfaction

\begin{tabular}{|c|c|}
\hline \multicolumn{2}{|c|}{ Reliability Statistics } \\
\hline Cronbach's Alpha & N of Items \\
\hline .881 & 6 \\
\hline
\end{tabular}

Table 5 is the overall reliability of the questionnaire. The findings of the table suggested that the overall reliability of the questionnaire is .881. The findings suggest that the questionnaire is overall reliable.

Table 6 Regression Coefficient of Service Quality Parameters and Customer Satisfaction

\begin{tabular}{|c|c|c|c|c|c|c|c|c|}
\hline \multirow{2}{*}{\multicolumn{2}{|c|}{ Model }} & & \multicolumn{2}{|c|}{$\begin{array}{l}\text { Unstandardized } \\
\text { Coefficients }\end{array}$} & \multirow{2}{*}{$\begin{array}{c}\text { Standardized } \\
\text { Coefficients } \\
\text { Beta }\end{array}$} & \multirow[b]{2}{*}{$\mathrm{t}$} & \multirow[b]{2}{*}{ Sig. } & \multirow[b]{2}{*}{ VIF } \\
\hline & & & $\mathrm{B}$ & Std. Error & & & & \\
\hline \multirow[t]{11}{*}{1} & (Constant) & & .100 & .218 & & .460 & .647 & \\
\hline & \multirow[t]{2}{*}{ Tangibility } & Expected & .103 & .047 & .133 & 2.207 & .029 & 1.603 \\
\hline & & Perceived & -.025 & .104 & -.020 & -.242 & .809 & 1.562 \\
\hline & \multirow[t]{2}{*}{ Reliability } & Expected & .134 & .044 & .186 & 3.061 & .003 & 1.633 \\
\hline & & Perceived & .030 & .091 & .033 & .329 & .743 & 2.392 \\
\hline & \multirow[t]{2}{*}{ Responsive } & Expected & .047 & .047 & .065 & 1.014 & .312 & 1.825 \\
\hline & & Perceived & .194 & .085 & .175 & 2.285 & .024 & 1.366 \\
\hline & \multirow[t]{2}{*}{ Assurance } & Expected & .137 & .053 & .160 & 2.582 & .011 & 1.690 \\
\hline & & Perceived & -.063 & .136 & -.054 & -.466 & .642 & 3.067 \\
\hline & \multirow[t]{2}{*}{ Empathy } & Expected & .540 & .068 & .520 & 7.920 & .000 & 1.909 \\
\hline & & Perceived & .548 & .104 & .530 & 5.246 & .000 & 2.369 \\
\hline
\end{tabular}


Table 6 above shows the finding of the coefficient of regression parameter used in the study to evaluate the unit change in the customer satisfaction due to the service quality in the private sector universities in KPK. The value of beta for the tangibility which has been used as a factor for the service quality is .133 which means that the customer satisfaction will be increased by .133 units when the tangibility in the service quality is increased by 1 unit. The sign of the beta is positive which suggested that the change in the customer satisfaction will be positive when the tangibility is increased. The value of t-value for the tangibility is 2.2 which are more than the standard value i.e. 2. The result shows that the tangibility is having positive and significant effect on the customer satisfaction. The beta value has been change from .133 to -.020 which shows that the tangible of the service quality shows a negative change. The $t$-value was significant when they expected and found higher insignificant when they entered to the sample area.

The value of beta in table 6 for the reliability which has been used as a factor for the service quality is .186 which means that the customer satisfaction will be increased by .186 units when the reliability in the service quality is increased by 1 unit. The sign of the beta is positive which suggested that the change in the customer satisfaction will be positive when the reliability is increased. The value of t-value for the reliability is 3.0 which are more than the standard value i.e. 2. The result shows that the reliability is having positive and significant effect on the customer satisfaction. The beta value has been change from .186 to .030 which shows that the reliability of the service quality shows a negative change. The t-value was significant when they expected and found higher insignificant when they entered to the sample area.

The value of beta in table 6 for the responsiveness which has been used as a factor for the service quality is .065 which means that the customer satisfaction will be increased by .065 units when the responsiveness in the service quality is increased by 1 unit. The sign of the beta is positive which suggested that the change in the customer satisfaction will be positive when the responsiveness is increased. The value of $\mathrm{t}$-value for the responsiveness is 1.01 which is lower than the standard value i.e. 2. The result shows that the responsiveness is having positive and insignificant effect on the customer satisfaction. The beta value has been change from .065 to .175 which shows that the responsiveness of the service quality shows a positive change. The $t-$ value was insignificant when they expected and found higher significant when they entered to the sample area.

The value of beta in table 6 for the assurance which has been used as a factor for the service quality is .160 which means that the customer satisfaction will be increased by .160 units when the assurance in the service quality is increased by 1 unit. The sign of the beta is positive which suggested that the change in the customer satisfaction will be positive when the assurance is increased. The value of $t$-value for the assurance is 2.5 which are lower than the standard value i.e. 2. The result shows that the assurance is having positive and insignificant effect on the customer 
satisfaction. The beta value has been change from .160 to -.054 which shows that the assurance of the service quality shows a negative change. The t-value was significant when they expected and found higher insignificant when they entered to the sample area.

The value of beta in table 6 for the empathy which has been used as a factor for the service quality is .520 which means that the customer satisfaction will be increased by .520 units when the empathy in the service quality is increased by 1 unit. The sign of the beta is positive which suggested that the change in the customer satisfaction will be positive when the empathy is increased. The value of t-value for the empathy is 7.9 which are higher than the standard value i.e. 2. The result shows that the empathy is having positive and significant effect on the customer satisfaction. The beta value has been change from .520 to .530 which shows that the empathy of the service quality shows a positive change. The t-value was highly significant when they expected and found significant when they entered to the sample area.

Hypotheses Testing

\begin{tabular}{|l|l|l|}
\hline H. No. & Hypotheses & Proved / Disproved \\
\hline H-.1 & $\begin{array}{l}\text { There is significant relationship between } \\
\text { tangibility of service quality and students } \\
\text { satisfaction. }\end{array}$ & Disproved \\
\hline H-2 & $\begin{array}{l}\text { There is significant relationship between } \\
\text { reliability of service quality and students } \\
\text { satisfaction }\end{array}$ & Disproved \\
\hline H-3 & $\begin{array}{l}\text { There is significant relationship between } \\
\text { responsiveness of service quality and } \\
\text { students satisfaction. }\end{array}$ & Approved \\
\hline H-4 & $\begin{array}{l}\text { There is significant relationship between } \\
\text { assurance of service quality and students } \\
\text { satisfaction. }\end{array}$ & Disproved \\
\hline H-5 & $\begin{array}{l}\text { There is significant relationship between } \\
\text { empathy of service quality and students } \\
\text { satisfaction. }\end{array}$ & Approved \\
\hline
\end{tabular}

\section{Results \&Discussion}

The purpose of the research study was to analyse differences in perceived quality in higher education sector between private and public universities, and also to measure and investigate the key dimensions in perceived service quality (Porral\& LevyMangin, 2013). The data was collected from students using modified SERVQUAL instrument then mean comparison and covariance structure analysis approach was done to measure the differences in perceived service quality between private and public universities. The finding suggested that tangibility and empathy are the most influent variables on perceived service quality in higher education sector. The sample of the study was only limited to undergraduate university students. Furthermore the research urged that higher education institutions develop and enhance different kinds 
of service quality strategies for the improvement of their institutions (Porral\& LevyMangin, 2013).

A research conducted with the title service quality, customer satisfaction and loyalty: a test of mediation in Malaysia to clarify the relationship between three variables and to describe better understanding of these variables. Data were gathered through survey technique on the basis of cross sectional method using SERQUAL. The result of the study show that there is a positive relationship among all five determinants of service quality with satisfaction and loyalty and also suggest that customer expectations are beyond their perception of the performance. The results further suggested that assurance and tangibles have the most and least relation with satisfaction (Mosahab, Mahamad, \&Ramayah, 2010).

The most dangerous threat to public higher education institutions is the intensity of competition predominantly from private HEI which seem to be more flexible and market oriented (Stimac\&Simic, 2016). As students are considered the prime customers of a university (Hill, 1995), being the direct beneficiaries of the service provided. Therefore, students perceived service quality should be taken into consideration as an exceedinglysignificant factor by the universities and their management. It is serious for higher education institutions to enthusiasticallyobserve the quality of their service and ensure the true realization of the interests of stakeholders during the realisation of their needs and wants (Basheer\& Ahmad, 2012). In today's competitive era, higher education institutions have to ensure the true satisfaction of their students' and for this they must understands the gap between students expected and perceived satisfaction and service quality. The literature reviewed observed that a significantly negative gap in the expectations and perceptions of the service quality signposts a sense of dissatisfaction among the students towards their institution of higher education. (Chopra, Chawla, \& Sharma, 2014).

Universities are important for generation, preservation and dissemination of knowledge in order to contribute to socio economic development of a nation(Donlagic\&Fazlić, 2015). The finding of the Dib \&Alnazer (2017) study recommended that universities must concentrate on servicequality that is one of the most important determinant of student satisfaction such as by narrowing the gap between expected and perceived service quality of the students. According to Khan, Ahmed, \& Nawaz (2011), there was a significant relationship between reliability, assurance, responsiveness and empathy with students' satisfaction while tangible had an insignificant relationship with satisfaction in higher education sector. The conclusion of the study urged that there is a negative gap between expectations and perceptions of the students. Hence, higher education institutions are being pressured to assess quality of their services and establish methods for improving quality(Donlagic\&Fazlić, 2015). Barnes (2010) the service quality using SERVQUAL instrument to investigate expectation and perception of students among a sample of post graduate Chines students and business and management school in the UK. Chopra, Chawla, \& Sharma studied (2014) to investigate service quality in higher education, with a comparative analysis of management and education 
institutions in India. The research studies the students' expectation and perception of service quality in the educational environment, using the modified SERVQUAL tool to measures the constructs of the model. The findings of the research suggested that significantly negative gap is observed in the expectation and perception of the service quality of higher education students.

Another study conducted by Naidoo (2014) to measure the perception of students service quality at South African university using adapted SERVQUL measurement tool. To increase students enrolment universities are now using their excellence in service quality to increase their market share. To improve service quality within the organization in order to create competitive advantage universities have to be market oriented. The findings of the study indicated that students were dissatisfied with the university service offerings(Naidoo, 2014).

Another study conducted in Malaysia in the context of adult learner especially in the context of off-campus program to assess student's service quality gap at two different centres(Shaari, 2014). The study urged that there is a significant difference in tangibility, reliability and empathy, therefore, institutions needs to address the emerging demand for quality in education industry to take corrective action at their centre(Shaari, 2014).

The quality of education provided in higher education institutions is a matter of debate in every country(Datta\&Vardhan, 2017). In the study of the quality of management education provided in United Arab Emirates (UAE) has also been a hot topic in the forefront. The finding of the study recommended the gap between perception and expectation of the students among responsiveness, assurance, tangibility, reliability and empathy(Datta\&Vardhan, 2017).

The finding of the Huang (2009) revealed that service quality as measured by SERVQUAL has a significant positive impact on customer satisfaction. The conclusion of the Mosahab, Mahamad, \&Ramayah, (2010) research shows that there is a positive and meaningful relation among all fivefold dimensions of service quality with customer satisfaction. The findings of Bharwana, Bashir, \&Mohsin (2013) depicts that four dimensions of SERVQUAL including tangibles, responsiveness, reliability and assurance are positively linked with customer satisfaction and one perspective that is empathy negatively related with satisfaction. On the other hand, Munhurrun, Naidoo, \&Lukea-Bhiwajee (2010) found that SERVQUAL dimensions have significantly negative relationship with an employee overall satisfaction. Many researchers recognized that level of satisfaction is based on the level of service quality (Tefera\&Govender, 2017; Khan \&Fasih, 2014; Markovic\&Jankovic, 2013). The finding of Ibraheem (2016), suggested that empathy and assurance positively and significantly correlated with students satisfaction in the university.

\section{Conclusion}

Pakistan is a developing country with its struggling socio-economic sectors and handful of investment in its human capital development through higher education institutions is the promising recipe. Universities create knowledge through research and transmit it to the target students through teaching in the human resource 
development process. Hence, Higher education sector, in Pakistan in general and in $\mathrm{KP}$ in particular, must keep excellence in knowledge creation and knowledge transmission as their prime objectives. Pakistan's higher education sector must keep its focus on satisfying its students challenging needs through quality education. This may call for faculty development, training in teaching pedagogy, incentives andexposure to finestfunctioning practices besides, developing learning friendly environment for learners.

The findings of the study shows that the service quality is narrowly and positively associated with customer satisfaction in higher education industry. Therefore, the survival and growth of higher education sector is directly related to the service quality it provides to its customers. The management of each institution of higher learning must understand that the delivery of better service quality is the leading area that increase the satisfaction of the customers and thereby help in increase in intake and retentions of their students throughout the length of their program without any intention of turning over or migrating to other institution. Satisfaction of extant students not only enhances institutional image, rather it attract new comers through their mouth marketing. Therefore, universities must be rational in developing strategies to create win win situation for the institutions and customers. This study was limited only to six universities, three each from public and private sectors, of Khyber Pakhtunkhwa. Future researchers are recommended to take into account the all universities, and also increase the number of variables as mediating or moderating variables.

\section{REFERENCES}

Abdullah, F. (2005). HEdPERF versus SERVPERF: The quest for ideal measuring instrument of service quality in higher education sector. Quality Assurance in Education, 13(4), 305-328.

Abdullah, F. (2006a). The development of HEdPERF: A new measuring instrument of service quality for the higher education sector. Interational Journal of Consumer Studies, 30(6), 569-581.

Abdullah, F. (2006b). Measuring service quality in higher education: HEdPERF versus SERVPERF. Marketing Intellignece and Planing, 1, 31-47.

Ali, F., Zhou, Y., Hussain, K., \& Nair, P. K. (2016). Does higher education service quality effect student satisfaction, image and loyalty?: A study of international in Malaysian public universities. Quality assurance in education, 24, 70-94.

Athiyaman, A. (1997). Linking student satisfaction and service quality perceptions: the case of university education. European Journal of Marketing, 31(7), 528540.Baker and Lamb, (1993). SERVQUAL: review, critique, research agenda.European Journal of Marketing 30(1):8-32

Asaduzzaman, Rahman, M., \& Hossain, M. (2013). Service quality and student satisfaction: A case study onprivate universities in Bangladesh. International Journal of Economics, Finance and Management Sciences, 1(3), 128-135.

Beaumont, D. (2012). Service quality in higher education: The students' viewpoint. Manchester: University of Manchester. 
Cayanan, C. D. (2017). Service quality of private tertiary education institutions in the province of Pampanga: A gap analysis. DLSU Research Congress 2017. Manila: De La Salle University, Manila, Philippines

Cronin, J., \& Taylor, S. (1992). Measuring service quality: a re-examination and extension. Journal of Marketing, 56(3), 55-68.

Cronin, T., \& Taylor, S. (1994). SERVPERF versus SERVQUAL: reconciling performance-based and perceptions-minus-expectations measurement of service quality. Journal of Marketing, 58, 125-131.

Datta, K. S., \& Vardhan, J. (2017). A SERVQUAL-based framework for assessing quality of international branch campuses in UAE: A management students' perspective. journals.sagepub.com/home/sgo, 1-9.

Douglas, J., Douglas, A. \& Barnes, B., 2006. Measuring student satisfaction at a UK university. Quality Assurance in Education, pp. 251-267.

Datta, K. S., \& Vardhan, J. (2017). A SERVQUAL-based framework for assessing quality of international branch campuses in UAE: A management students' perspective. journals.sagepub.com/home/sgo, 1-9.

Donlagic, S., \& Fazlić, S. (2015). Quality assessment in higher education using using the SERVQUAL model. Management, 20, 39-57.

Ducombe, R., \&Boateng, R. (2009). Mobile phones and financial services in developing countries: A review of concepts, methods, issues, evidence and future Research. Third world quarterly, 30(7), 1237-1258.

Elliot, K. M., \& Shin, D. (2002). Student Satisfaction: An alternative approach to assessing this important concept. Journal of Higher Education Policy and Management, 24(2), 197-209.

Eurydice. (2017). Modernisation of Higher Education in Europe: Academic Staff. Luxembourg: Education, Audiovisual and Culture Executive Agency (EACEA, Education and Youth Policy Analysis).

Farahmandian, S., Minavand, H. \&Afshard, M., 2013. Perceived service quality and student satisfaction in higher education. Journal of Business and Management, pp. 12 (4), PP 65-74.

Felix, R. (2017). Service quality and customer satisfaction in selected banks in Rwanda. Journal of Business \& Financial Affairs, 6.

Fick, (1991). Measuring Service Quality in the Travel and Tourism Industry

Garcl a-Aracil, A., 2009. European graduates' level of satisfaction with higher education.

Journal of Higher Education, 57(1), pp. 1-21.

Ghotbabadi, A. R., Feiz, S., \& Baharun, R. (2015). Service quality measurement: A review. International Journal of Academic Research in business and social sciences, 267-286.

Gronroos. (1982). Strategic managent and marketing in the service sector. Swedish school of economics and business administration. 
Gronroos. (1984). A servic quality model and its marketing implications. European Journal of Marketing, 18(4), 36-44.

Hair, J. F., Black, W. C., Babin , B. J., Anderson, R. E., \& Tatham, R. L. (2006). Multivariate data analysis (6 ed.). Singapore: Prentice-Hall.

Hu, L., \& Bentler, P. (1999). Cutoff criteria for fit indices in covariance structure analysis: conventional criteria versus new alternatives. Structural Equation Modeling. IBM $®$ SPSS $®$ Amos(TM) 25.

HEC. (2014). Annual report 2013-2014. Isalamabad: Higher education commission Pakistan.

HEC. (2016). Hihger education commission of Pakistan. Hihger education commission of Pakistan.

Ho, S. K., \& Wearn, K. (1996). A higher education TQM excellence model: HETQMEX.

Quality Assurance in Education, 35-42

Ibraheem, M. K. (2016). Relationship between perceived service quality and student's satisfaction among undergraduate students: A case study of private higher education institute in Dubai. International Journal of Emerging Research in Management \&Technology, 5(3), 70-74.

Jain, P., \& Aggarwal, V. S. (2015). Service quality models: A review. BVIMSR's Journal of Management Research, 125-136.

Khan, M. M., \&Fasih, M. (2014). Impact of service quality on customer satisfaction and customer loyalty: Evidence from banking sector. Pakistan Journal of Commerce and Social Sciences, 8(2), 331.

Khan, M. M., Ahmed, I. \& Nawaz, M. M. (2011). Student's perspective of service quality

in higher learning institutions; An evidence based approach. International Journal of Business and Social Science, 2(11), pp. 159-164.

Kara, A. M., Tanui, E., \& Kalai, J. M. (2016). Educational service quality and students' satisfaction in public universities in Kenya. International Journal of Education and Social Science, 10(3), 37-48.

Kawshalya, N. (2016). Models of service quality- A brief literature review. SQPM, Essex, United Kingdom.

Khalifa, B., \& Mahmoud, A. B. (2016). What form university image? An integrated model from Syria. Verslas: Teorija ir praktika / Business: Theory and Practice, 17, 45-55.

Khurana, S. (2017). Relationship between service quality and customer satisfaction: An empirical study of indian life insurance industry. Journal of Research in Marketing, 1(2), 35-42.

Kotler, P. (1991). Marketing Management: Analysis, Planning, Implementation \& Control (7 ed.). New York: Prentice - Hall.

Kotler, P., Armstrong, G., Saunders, J., \& Wong, V. (2002). Principle of Marketing (3 ed.). Europe: Pretence Hall. 
Kline, R. B. (2011). Principles and practice of structural equation modeling (3 ed.). New York: The Guilford Press.

Krejcie, R., \& Morgan, D. (1970). Determining sample size for research activities. Educational and Psychological Measurement, 607-610.

Krishnamoorthy, V., Aishwaryadevi, A. S., \& Bharathi, B. (2016). An examination of influence of higher education service quality on students' satisfaction: An Indian perspective. IMR (Indira Management Review), 10(2), 95-102.

Lee and Moghavvemi, (2015). The Dimension of Service Quality and Its Impact on Customer Satisfaction, Trust, and Loyalty: A Case of Malaysian Banks. Asian Journal of Business and Accounting 8(2), 2015. 92.

Lehtinen, U., \& Lehtinen, J. R. (1991). Two approaches to service quality dimensions. The Service Industries Journal, 11(3), 287-303.

Liben, G., Daniel, D., \& Adugna, A. (2017). Assessment of students' satisfaction: A case study of Dire Dawa University, Ethiopia. Journal of Education and Practice, 8(4).

Lien, P. T. (2017). Training service quality and its effects on student satisfaction: Case of a Vietnam University. International Journal of Academic Research in Business and Social Sciences, 7(4).

Malik, S. U. (2012). Customer satisfaction, perceived service quality and mediating role of perceived value. International Journal of Marketing Studies, 4, 68-76.

Meštrović, D. (2017). Service quality, students satisfaction and behavioural intentions in STEM and IC higher education institutions. Interdisciplinary Description of Complex Systems, 15, 66-77.

Mwiya, B., Bwalya, J., Siachinji, B., Sikombe, S., Chanda, H., \& Chawala, M. (2017).

Higher education quality and student satisfaction nexus: Evidence from Zambia. Creative Education, 8, 1044-1068.

Nawaz, M. N., \& Gomes, A. M. (2014). Review of knowledge management in higher education institutions. European Journal of Business and Management, 71-79.

Noel-Levitz. (2010). Customer satisfaction measures. Washington, DC: Hanover Research.

Navarro, M. M., Iglesias, M. P. \& Torres, P. R. (2005). A new management element for

universities: satisfaction with the offered courses. International Journal of Educational Management, 19(6), pp. 505-526.

Nunnally, J. O. (1978). Psychometric Theory.New York: McGraw-Hill.

Onditi, E. O., \& Wechuli, T. W. (2017). Service quality and student satisfaction in higher education institutions: A review of literature. International Journal of Scientific and Research Publications, 7(7), 328-335.

Palacio, A. B., Meneses, G. D., \& Perez, P. J. (2002). The configuration of the university image and its relationship with the satisfaction of students. Journal of Educational Administration, 40(5), 486-505.

Pallant, J. (2011). SPSS Survival manual: A step by step guide to data analysis using SPSS for windows (4 ed.). McGraw Hill: Open University Press. 
Parasuraman, A., Zeithaml, V., \& Berry, L. (1985). A conceptual model of service quality and its implication for future research. Journal of marketing, 41-50.

Parasuraman, A., Zeithaml, V., \& Berry, L. (1988). SERVQUAL: A multiple-item scale for measuring consumer perceptions of service quality. journal of Retailing, 64(1), 12-40.

Prasad, R. K., \& Jha, M. K. (2013). Quality measures in higher education: A review and conceptual model. Quest Journals journal of research in business and management(3), 23-40.

Quyet, Vinh and Chang, (2015). Service Quality Effects on Customer Satisfaction in Banking Industry

Razali, M., Nor, K., Talib, N., Ahmad, N., Baharan, R., Sakarji, S., et al. (2017). The study of relaitonship between service quality and customer satisfaction among staff at Mahkamah Persekutan Malaysia. Journal of Humanities, Language, Culture and Business (HLCB), 1(2), 152-167.

Saleem, M., Ch., A. H., \& Ahmad, S. (2017). Identification of Gaps in Service Quality in Higher Education. Bulletin of Education and Research, 39(2), 171182.

Saunders, M., Lewis, P., \& Thornhill, A. (2009). Research Methods for business students (4 ed.). Pearson education limited.

Sojkin, B., Bartkowiak, P. \&Skuza, A., 2012. Determinants of higher education choices 565-81.

and student satisfaction: the case of Poland. Higher Education, 63 (5), pp.

Sultan, P., \& Wong, H. Y. (2012). Service quality in a higher education context: An integrated model. Asia Pacific Journal of Marketing and Logistics, 24, 755784.

Saravanan, L. (2018). A study of students satisfaction level towards service quality of teachereducation colleges with special reference Erode district. Shanlax International Journal of Commerce, 6(1), 52-58.

Suvittawat, (2015).Effective Inventory Management of Entrepreneurs in Eastern Part Thailand:

Stodnick, M., \& Rogers, P. (2008). Using SERVQUAL to measure the quality of the class room experience. Decision Sciences Journal of Innovative Education, 6(1), 115-133. http://dx.doi.org/10.1111/j.1540-4609.2007.00162.

Tabachnick, B. G., \&Fidell, L. S. (2001).Using multivariate statistics (4th edn). New York: HarperCollins.

Tan, Oriade and Fallon, (2014).Exploring customer satisfaction with university cafeteria food services.An empirical study of Temptation Restaurant at Taylor's University, Malaysia.A Proposal HariDwiUtami - Business \& Economics 
Tegambwage, A. G. (2017). The relative importance of service quality dimensions: An empirical study in the Tanzanian higher education industry. International Research Journal of Interdisciplinary \& Multidisciplinary Studies (IRJIMS), 76-86.

Teeroovengadum, V., Kamalanabhan, T. J., \& Seebaluck, A. K. (2016). Measuring service quality in higher education Development of a hierarchical model (HESQUAL). Quality Assurance in Education, 24(2), 244-258.

Tefera, O., \& Govender, K. (2017). Service quality, customer satisfaction and loyalty: The perceptions of Ethiopian hotel guests. Journal of Hospitality, Tourism and Leisure, 6(2), 1-22.

Wilkins, S., \& Balakrishnan, M. S. (2013). Assessing student satisfaction in transnational higher education. International Journal of Educational Management, 27(2), 143-156.

Yusoff, M., McLeay, F. \&Woodruffe-Burto, H., 2015. Dimensions driving business student satisfaction in higher education. Quality Assurance in Education, pp.

$86-104$.

Yusof, A., \& Joseph, J. (2017). Customer's expectation, perception and satisfaction with service quality of a fitness center in Malaysia. International Journal of Physical Education, Sports and Health, 4(1), 146-150.

Zeithaml. (1988). Consumer perceptions of price, quality, and value: A means-end model and synthesis of evidence. journal of marketing, 2-22.

Zeithaml, A. V., Parasuramn, A., \& Berry, L. L. (1985). Problems and strategies in service marketing. Journal of Marketing, 49(2), 33-46. 